\title{
IMPACT OF INNOVATIONS UPON ECONOMIC GROWTH DURING RECESSION
}

\author{
Vytautas SNIESKA, Gitana VALODKIENE \\ Department of Economics, Kaunas University of Technology, \\ K. Donelaičio g. 20, LT- 44239, Kaunas, Lithuania
}

Received 20 November 2014; accepted 18 April 2015

\begin{abstract}
The role of the factors influencing economic growth during economic recessions and the role of these factors in separate economic phases are analysed. The purpose of the research is to assess the impact of innovations on economic growth during recession. The analysis of the situation in manufacturing sectors of Lithuania during economic recession in 2007 to 2009 has revealed several characteristics of innovations for this period due to which Lithuanian manufacturing enterprises managed to successfully function and remain competitive. The influence of household consumption expenditure on the growth of GDP in Lithuania is described by the function close to the linear, so we see a direct relation between these two variables. The influence of export on GDP is described by a convex function which has showed the declining influence of export on the GDP growth in the long-term perspective. Thus, contrary to a rather popular belief in transition countries, the main engine of growth in the long-term is not export. The long-term GDP growth is impossible without stimulating the growth in household consumption expenditure.
\end{abstract}

Keywords: innovations, economic recession, competitiveness, Lithuanian industry, economic growth, economic growth theories.

JEL Classification: F14, F43, L60, E32, E61, F44, O33.

\section{Introduction}

Macro-economic stability of the nation's economy is the base of its competitiveness and growth. When focusing on long-run perspectives of economic growth, it is important to impartially distribute material investments. Unbalanced investments lead to much deeper economic recession. Before the economic recession in 2007, the investments into real estate were too large, while the expenditure had to be distributed more effectively by investing into mechanical engineering and equipment.

Corresponding author Vytautas Snieska

E-mail: vytautas.snieska@ktu.lt 
It is necessary to create a firm basis which would ensure high production quality based on solid control mechanism, and would determine fundamentals for successful competition in international markets.

When pursuing positive results in the innovativeness field, an enterprise has to perform an in-depth analysis of the market and business environment. Sometimes, uptake of innovations fails because, as Franklin (2003) states, businesses ignore tendencies dictated by the market and business environment. According to Franklin (2003), the success of enterprise innovativeness is determined by feedback management, group thinking and great optimism about demand for its product.

Theories of economic growth distinguish a lot of factors that are more or less important in analysing the economic growth both at micro- and macro-economic level. At macro-economic level, the economic growth is outlined by referring to the change of GDP volumes. In scientific literature the opinion that it is not sufficient to refer only to GDP indicator when outlining the economic growth of the economy is more often expressed. GDP shows only static state and its dynamics, i.e. the change of static states, yet it does not reveal what factors determine the shift from one GDP state to another.

Theories of economic growth refer to different factors stimulating economic growth as well as coherences among these factors.

In analysing economic growth, scientific literature distinguishes not only endogenous but also exogenous factors of growth (models of Ramsey (1931), Solow (1956), (Barro (1988) and Romer (1990)). The same factors can be considered to be exogenous and endogenous by different authors.

Some authors, such as Solow (1956) and Barro (1988), analyse economic growth by referring to the classical model of economic growth according to the Cobb-Douglas production function $Q=f(K, L)$. The model states that it is not important what social-economic changes would take place in the country; work and capital, which being influenced by the factor of time change acquire a new form, remain the main production factors. Thus the relationship of these factors changes during certain production processes. The changes are stimulated by increasing the needs of consumers, by technological and scientific advancements, and by innovative progress that leads from old into new.

The Solow (1956) growth model complemented the Harrod-Domar model by adding the new coefficient of technology that changes over the time. He introduced work as a factor of productivity increase, and he considered that it was necessary to analyse decreasing work productivity and decreasing capital productivity separately by analysing them together with stable return of both factors due to their extent. This model does not consider that capital productivity and the coherence of work, i.e. capital ratio, are fixed as it was in the Harrod-Domar model.

Scientists analyse economic growth with focus on different aspects. In the context of the EU development (Ciegis et al. 2008), they identify coherence between economic growth and consumer trust (Celik, Ozerkek 2009); they emphasise the relevance of innovation policy for economic growth and competitiveness (Grundey et al. 2008). Some scientists give an important role to the development of agriculture, which is considered to be the source for industrial and economic growth (Byerlee et al. 2009). At present the impact of Research and 
Technological Development (R\&D) on economic growth is more often stressed by considering technological and ecological aspect as well as the possibility to decrease energy prices (Fisher-Vanden, Ho 2010). Still another emphasis is on the impact of infrastructure on social and economic development (Snieska, Simkunaite 2009).

In the development of the European Union, the role of human capital migration becomes relevant for country's economic growth (Cekanavicius, Kasnauskiene 2009). The possibilities of most enterprises to compete are limited by gaps in developing innovative activity. The problem is not only the lack of financing. Most enterprises do not resolve to make innovative decisions due to lack of information and the absence of instruments that would stimulate innovative activity. Moreover, small and medium-sized business enterprises face difficulties in getting financing sources and other problems. The increase of Lithuanian economic competitiveness is carried out fragmentarily, no consistency is observed; the activity of separate fields is not interconnected to one entity of purposeful activity.

The purpose of the research is to assess the impact of innovations on economic growth during recession.

Research methods used include the analysis of scientific literature, analysis of the existing models that describe the impact of innovations on economy, statistical analysis and modelling.

\section{Economic growth and competitiveness}

Solow (1956) was the first economist who created the growth model in which he distinguished different capital types in terms of time by paying his attention to the change of capital due to innovations, which in turn triggered the change in its productivity. In the Solow (1956) model, new capital is much more valuable than the old one; it changes from productive capital to knowledge intensive technologies, i.e. the development of technologies makes new capital more productive than the old one.

Solow (1956) paid attention to technological changes in time, and in the economic growth model $Y=A \times K^{\alpha} \times L^{\beta}$ he introduced the variable of technologies A. The author also introduced innovations through technologies. He disclosed that the return of work and capital factors decreased by increasing one of these factors; however, even increase of these factors gives stable return.

In his growth theories, Robert Barro (1988) focuses on coherences between innovations and investments. At different times certain factors characteristic of economic growth have become evident. This resulted in scientists complementing their economic growth models with them. Barro (1990) complemented his economic growth model based on the CobbDouglas production function by introducing the factor of governmental sector. He began an in-depth analysis of the growth process by investigating a qualitative aspect of economic development, i.e. such factors of economic growth as probable life duration, fertility, environment conditions, inequality in revenue distribution and different attributes of political institutions. The latter include democracy and existence of electorate rights, precedence of law and the level of public sector corruption. Barro also analyses criminal factors such as the frequency of murders, the role of religion in economic growth (he analysed international data on attendance of churches and doxies). 
Romer (1990) investigated economic growth in the long run. The author's economic growth model referred to balanced competitiveness. However, this balance is not optimal. High pace of growth can be achieved through investments. According to the author, underdeveloped countries, which have better management systems and institutions, have more favourable possibilities for economic growth. In his works the author emphasises the importance of technological advancement, capital accumulation and development of research and technologies for economic growth. In his economic growth theory Romer considers private participants of the market that influence the results of technological progress.

The Rebelo (1991) growth model states that a production function is linear with the only factor of capital.

The Ickes (1996) economic growth model emphasises the role of endogenous growth factors. Constant return and constant capital return; according to the author, the production function is $Y=F(K, L)=A K$, where $A$ is an exogenous variable and $K$ is capital in a broad sense (i.e. it is not only physical but also human capital as well as knowledge resources and financial capital). According to this model "the growth rate of an economy depends on its savings rate and on the productivity of its technology" (Ickes 1996).

The model of economic growth by Ramsey (1931) differs from the model of economic growth by Solow so that it includes the change of consumption at chosen time points.

The neo-classical model was supplemented by the model of Harrod-Domar in 1946 in introducing a new term, i.e. productivity growth. Basic contribution of these authors to the model is that they introduced the maximization of consumption function in households.

Kamer Daron Acemoğlu analysed economic growth (Acemoglu et al. 2005), the impact of market size on innovations (Acemoglu, Linn 2004), human capital development, technologies and other fields of economics. Together with his colleagues he also investigated the role of institutions in economic development and political economy in terms of income and wage differences (Acemoglu et al. 2002).

In modern-day scientific articles economic growth is related to country's attractiveness to Foreign Direct Investments (FDI) (Amdam et al. 2007); the changes in separate economic sectors stimulated by the EU support, human capital and new technologies have a positive influence on country's economic growth (Kokocinska 2009). When analysing regional economic growth, some scientists consider qualified work power, Research and Technological Development (R\&D) and innovations as the main stimulators of economy (Kroll, Tagscherer 2009), whereas others distinguish the following main factors: technological innovations, human capital, accessibility of economic structure and labour market (Pinto, Guerreiro 2010).

According to Boguslauskas and Adlyte (2010), economic growth of country increase with new workplaces and better social stability, influenced by successful activity and growth of enterprises.

Some attention is devoted to problems of small and medium business development and the coherence between the potential of technological innovations and economic growth. Technological innovations play a great role in the activity of small and medium enterprises and are closely related to economic growth (Yan 2009).

Most scientists admit an importance for country's economic growth rise and competitiveness growth as well as value added creation (Jasinskas, Simanaviciene 2008). 
In other papers scientists also analyse the relationship of economic growth and other economic factors. Katircioglu (2010) analyses coherence between international trade and economic growth; Lupu and Dumitrescu (2010) deal with coherences between economic growth and capital market; Memon and Demirdogen (2009) investigate intervention of technologies into social economic growth. Some scientific articles study the impact of employees working in separate activity fields on economic growth and draw the conclusion that in certain regions the activity of employees in technological and creative positions makes positive impact on economic growth (Wedemeier 2010). Zickiene (2007) analysed economic growth and sustainable development by considering problems of environmental control, coordinating collaboration among enterprises, environmental control institutions and the government. Tvaronavicius and Tvaronaviciene (2008) analysed the relationship between fixed investments and economic growth in Lithuania.

\section{Impact of innovations on competitiveness during the recession stage in terms of export and consumption}

One of the main aims of every country is to ensure volumes of increasing production and economic growth. When country's economy grows, GDP volumes, which outline the state of economy, also increase. In a time of economic recession GDP volumes decrease together with sales volumes and consumption. During recession, due to competition growth within local market, producers face more difficulties to sell their production. In order to guarantee at least stable sales volumes, producers have to choose one of two alternatives: to decrease production costs and prices or to offer a new improved product.

As Lithuanian economy is rather small and open, country's economic recovery does not unambiguously depend on local market only. Country's economic recovery depends on aggregate economic situation of markets both in the EU and around the world; it also depends on changes in export of Lithuanian products.

In open market economy producers feel much greater competitive pressure. Since Lithuanian market is open and small, it is complicated enough to remain competitive in respect of other countries. As economic recession started, GDP and domestic consumption volumes decreased, competition within domestic market increased. Due to increasing competition within domestic market, the need for innovations increases. The growth of international competitiveness became evident in export growth (Figs 1 and 2).

As the governments create favourable conditions for the development of business and science, the aggregate demand increases due to dissemination of innovation, which in turn stimulates economic growth.

Political environment beneficial for business can be created on easy terms as a result of laws stimulating entrepreneurship in the entire territory of the country when preferential taxes are indicated, grants and subsidies are provided, bilateral and multilateral business relations are developed through embassies as well as by other means which foster business both domestically and internationally.

Development of business and science as well as integrity of activity in these two sectors would create strong basis for country's economic growth. 


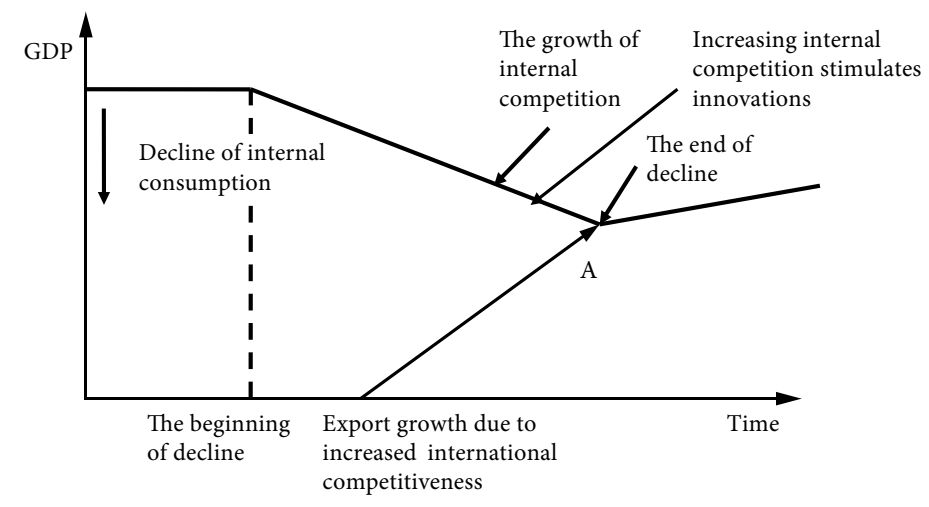

Fig. 1. The impact of recession on innovations in open market economy

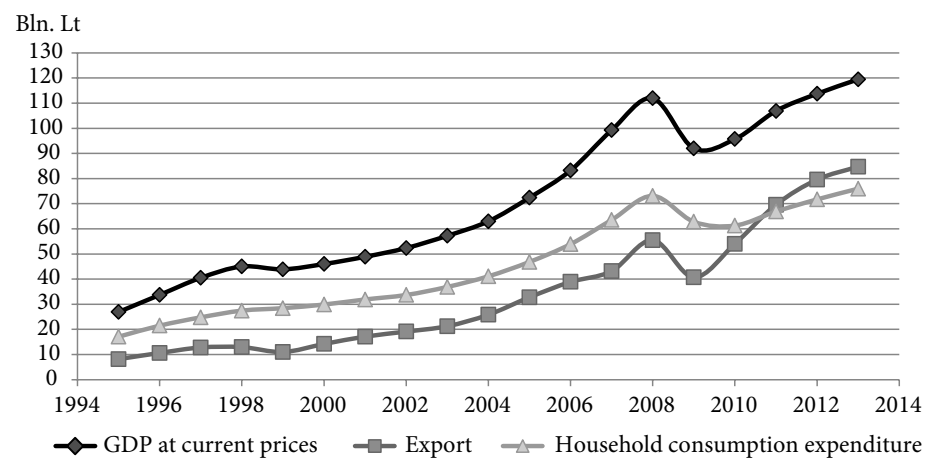

Fig. 2. Changes of GDP at current prices, export and household consumption expenditure in Lithuania Source: authors' calculations based on the Statistics Lithuania data (2015).

Due to innovations the aggregate demand increases both country's local market and foreign markets. The country's endogenous cycle of circulation inducing growth in demand takes place through labour market increasing household consumption by involving goods and service market as well as finance market. In open market economy the circulation of innovations that induce demand growth occurs by involving goods and service market and foreign trade.

The analysis of data presented in Figure 2 has showed that the relationship between export and GDP may be described by the polynomial regression function (Fig. 3):

$$
y=-0.0147 x^{2}+2.475 x+11.847
$$

with the determination coefficient $\mathrm{R}^{2}=0.9777$.

The relationship between household consumption expenditure and GDP may be described by the polynomial regression function (Fig. 4):

$$
y=0.0021 x^{2}+1.3475 x+4.3707,
$$

with the determination coefficient $\mathrm{R}^{2}=0.9966$. 


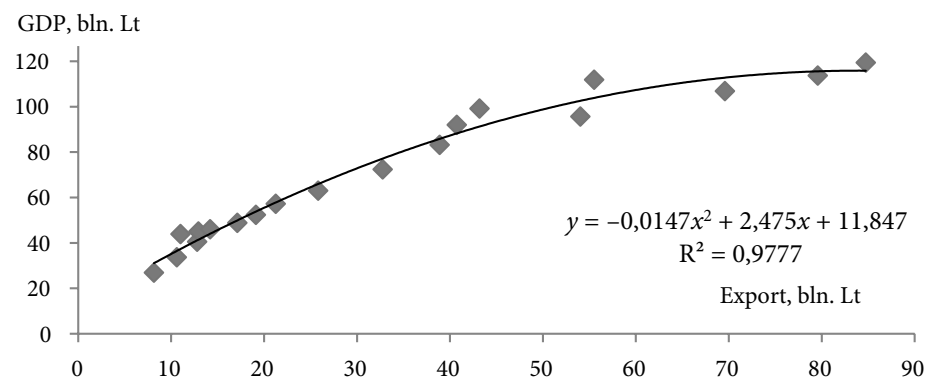

Fig. 3. The relationship between export and GDP, 1994 to 2013

Source: authors' calculations based on the Statistics Lithuania data (2015).

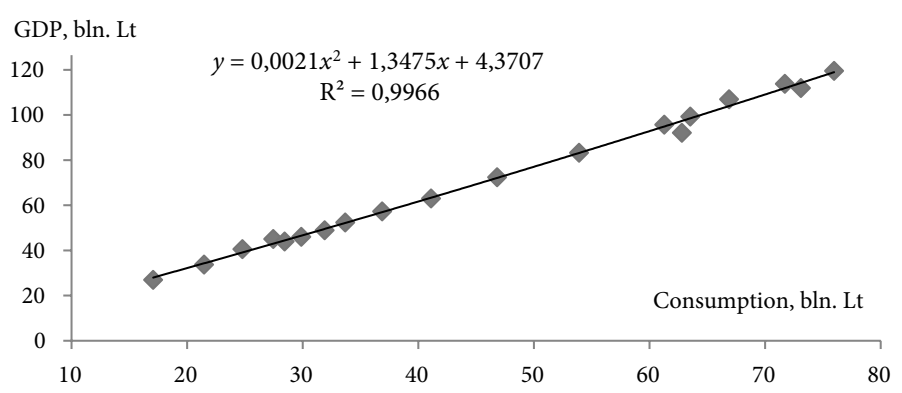

Fig. 4. The relationship between household consumption expenditure and GDP, 1994 to 2013

Source: authors' calculations based on the Statistics Lithuania data (2015).

Comparison of these two functions has showed that the influence of household consumption expenditure on the growth of GDP is described by the function close to linear, so we see the direct relation between these two variables.

The influence of export on GDP is described by the convex function, which has showed the declining influence of export on the GDP growth in the long-term perspective.

Misleading beliefs that export is the main impetus for long-term growth prevail in transition countries. However, the long-term GDP growth is impossible without the stimulation of growth in household consumption expenditure.

Things are different in the short-term perspective.

In Figures 5 and 6 a similar analysis is performed for the period just after the decline of 2008, i.e. 2009 to 2013. In this period the household consumption expenditure function has a convex shape, proving a diminishing significance of this factor for economic growth (Fig. 6):

$$
y=-0.0415 x^{2}+7.526 x-212.58,
$$

with the determination coefficient $\mathrm{R}^{2}=0.9437$.

The main reason for such tendencies of growth sources in Lithuania is the method which was used to solve problems in after-crisis period, namely labour deflation being the main method of balancing the states budged and getting good balance of payments of Lithuanian economy. 


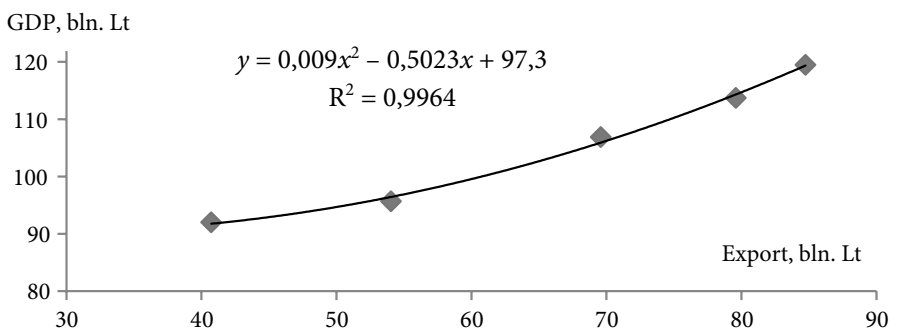

Fig. 5. The relationship between export and GDP, 2009 to 2013 Source: Authors' calculations based on the Statistics Lithuania data (2015).

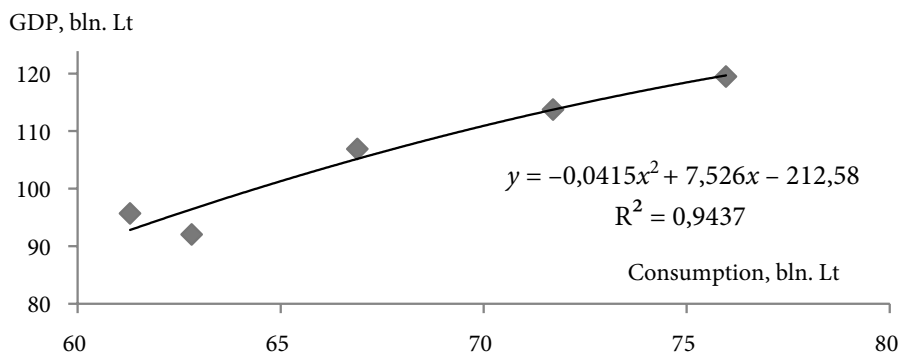

Fig. 6. The relationship between household consumption expenditure and GDP, 2009-2013 Source: authors' calculations based on the Statistics Lithuania data (2015).

When internal possibilities for economic growth were limited by the household consumption expenditure restrictions, business got the main niche and additional possibilities in export competition due to cheaper labour.

The polynomial regression function for export in the period 2009 to 2013 :

$$
y=0.009 x^{2}-0.5023 x+97.3
$$

was with the determination coefficient $\mathrm{R}^{2}=0.9964$.

Modelling the consequences of such type of growth has showed a serious obstacle for the growth in a longer period, i.e. continuing high rates of labour emigration due to uncompetitive wages in Lithuania will erode one of the main growth factors. Development of innovations that is more rapid than the decline of labour market will be the only prerequisite for growth. As Saboniene (2014) notices, "Moving towards the competition on quality, the knowledge and technology are increasingly becoming the drivers for competitiveness and growth whereas the competition on price (lower costs) is becoming complicated due to the rise of the costs of labour and resources" (Saboniene 2014).

Changes taking place due to innovations have not only destructive but also creative power; new workplaces, new perspectives for business development, new possibilities for households to use the services rendered by finance market occur. Innovations make the endogenous market space for business too narrow; thus new markets, new niches in them are searched for and unused possibilities are being checked. 
During the recession of global economy, the competitiveness of country's industrial enterprises is determined by economic and political environment (Fig. 7). Business and science development depends on legislation; however, legislation currently does not induce development of business and science in Lithuania, it impedes them. Present imperfect legislation system is a result of both innovations and business: unfavourable laws regulating establishment of enterprises and suspension of the activity, weak financing.

Brazinskas (2010) notices that when the market of real estate prospered, construction business which has been successfully developing and the demand which has increased in the local market have not created long-run premises for country's enterprises to prosper.

Business development would positively influence the business incentive by regulating taxes, rendering financial and non-financial support. Moreover, through the support of risk capital it would be possible to stimulate innovations.

In case favourable climate for innovations is formed, the possibility that this would stimulate the emergence of innovative enterprises exists. As Umbrasiene (2014) found, “There exists a faint tendency of decrease of sensitivity to cyclical changes as added value per employee increases" (Umbrasiene 2014).

The impact of innovations on labour market changes requirements for employees and creates additional workplaces (or decreases). Households are affected because the number of workplaces increases or decreases. In addition, people become more innovative (entrepreneurship increases). As economic environment improves, households become richer and stimulate innovations.

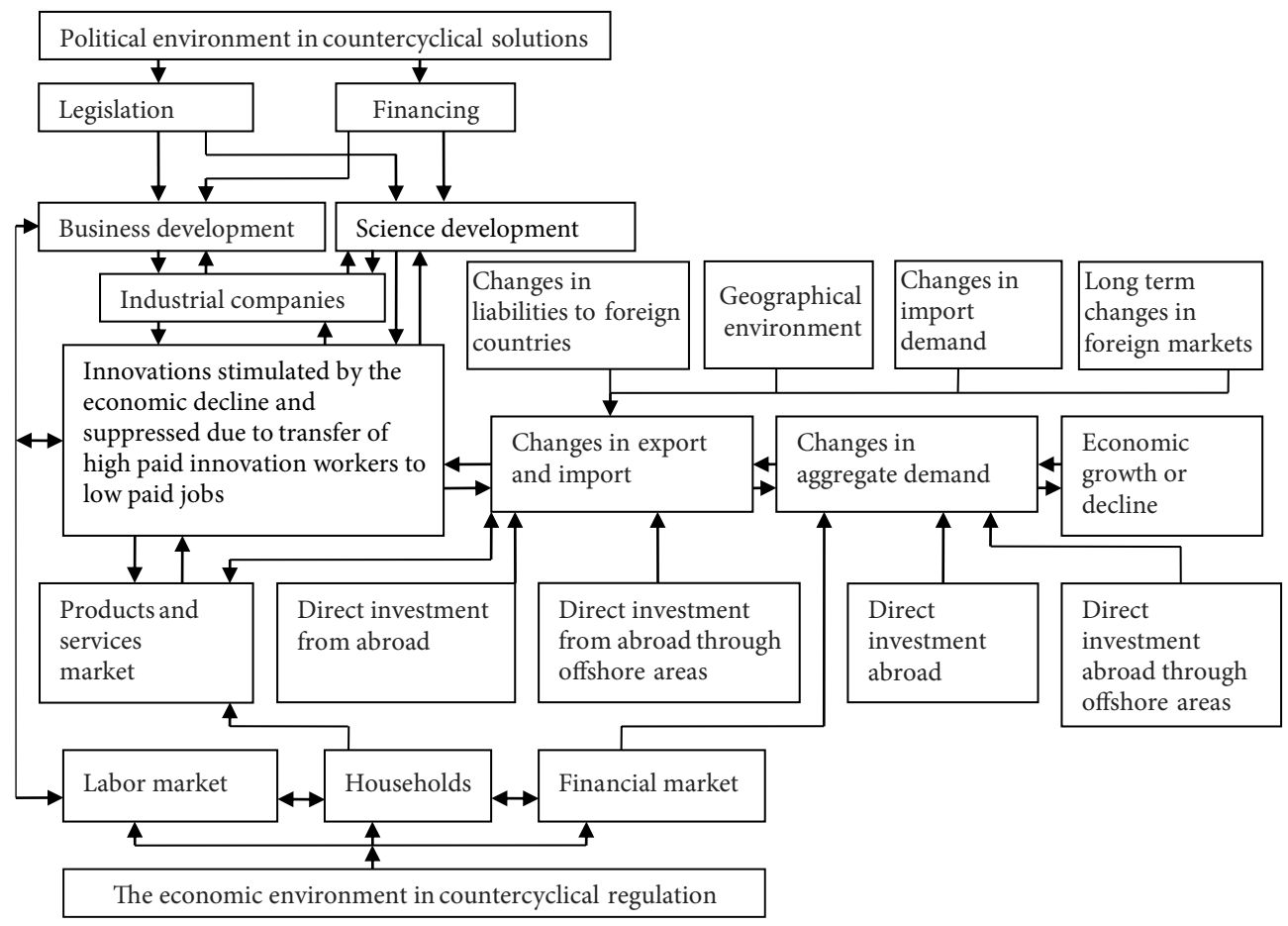

Fig. 7. Impact of innovations on international competitiveness during economic recession 
On the other hand, if the amount of household money decreases, the market of goods and services shrinks, and in such a market there are more possibilities to sell innovative products. If households want to buy more, then domestic enterprises produce or import more. If innovative goods emerge in goods and service market, possibilities for export occur.

Innovations can enlarge aggregate demand, whereas the change of aggregate demand also influences the change of innovativeness.

Starting with Schumpeter, most economists have tried to prove that economic recessions have positive effects because they create stimuli for enterprises to expand their effectiveness. On the other hand, research of other scientists, e.g. Stiglitz (1993), showed that economic variations also cause some losses which are incurred not only because they are provisionally not used as some resources but also because that productivity of economic future is negatively affected by decreased expenditure for research and development during crises.

Stiglitz has proved that these losses were much more important than any temporary achievements due to forced decrease of costs. The analysis of Schumpeter puts more emphasis on the impact of market structure on innovations and less emphasis on the imperfections of capital market, which affect technological progress in an extremely negative way during economic recession. Not only do economic fluctuations create variations in the process of innovations, but also variations of innovation process can cause economic fluctuations. As such a situation occurs economic balance can form due to different combinations; thus there is no ground to hope that free market alone will ensure the best decision without an exogenous impact. Having assessed the factor of financial market imperfections, it becomes evident that under recession the expenditure for research and development suffers especially because raw materials being bought or assets being acquired can become bail for banks, and innovations are always risky. In a recession phase they can put down the firm if the innovation fails; thus firms are in preference to other expenditure, and the consequence is the decrease of the expenditure for innovation stimulation. In addition, it is necessary to consider that in case of crisis banks stiffen requirements for credit rendering. Consequently, during economic recession the expenditure for research and development decreases not only because of decreased flows of money to investments but also because of strict policy of banks.

Firms also face decreased possibilities to collect additional money by selling additional stock emissions, as the emergence of such a wish coincides with the fall of present stock value and additional shares can be sold only much cheaper.

Stiglitz and other authors presented additional counterarguments for theories of Schumpeter. It is more likely that the process of natural selection taking place in the phase of economic recession will select not the firms that possess long-run growth potential but those that better stand present economic recession. Therefore, when carrying out selection of the most effective firms, it is probable that perspective firms with great potential in the future will be eliminated.

The Schumpeter analysis ignored the positive impacts of economic growth period on the increase of effectiveness. In addition, in the Schumpeter model a great gap between private costs and society costs in increasing enterprise effectiveness can emerge.

The main premise in most endogenous growth models is that innovations elaborate technological process; enterprises decrease their costs or increase demand due to innovations. 
Large enterprises, which can use advantages of the scale of production economy, can better use innovations. However, small enterprises functioning in competitive markets are forced to create better products by using the best technology; thus in a long run the innovations of small and medium enterprises destroy monopolistic rent. Innovations enlarge goods quality and decrease costs. Innovative enterprises can pro tem acquire monopolistic situation in the product market; on the other hand, innovations are related to market power and demand for products.

Empirical research of Smolny (2003) showed that demand shocks affected the volumes of prices and production in the short run and influenced the conditions of innovations and investments financing in the long run. Also this research showed that exporting enterprises were more subject to innovations; however, the level of exporters' investments is lower. Moreover, he identified that investments are more influenced by market competitiveness that the size of a firm.

Also the impact of innovation price on economic development becomes evident. If enterprises can get innovative products free of charge, this negatively influences investments into research development. For further research of this problem Multi-Criteria Decision Making (MCDM) models (Zavadskas et al. 2014) may give interesting results.

According to the classical macro-economic theory, which especially points out the aspect of supply and states that market powers ensure full employment, recessions destroy themselves without intervention of the government. However, long-running Great Depression caused doubts in sufficiency of the classical theory and made the Keynesian macro-economics, which stressed that the government can regulate aggregate demand through its tax policy and expenditure use, more popular. The government can especially effectively influence the part of aggregate demand related to the government's expenditure. It can also influence net exports by changing international trade policy and the tendency of population to save up through the regulation of inflation process. The part of aggregate demand related to investments into capital involves investments into new business or people buildings, buying of cars and equipment as well as the increase of reserves. The size of investments depends on investment return, which, in its turn, depends on expectations about changes of business environment, the size of existing reserves and mostly on the size of interest. The changes in aggregate supply curve are caused by the changes in resource provision, technology and government policy which influence costs or net imports. The increase in aggregate demand enlarges national income and GDP as well as the level of prices and employment. The development of aggregate supply decreases the level of prices and induces employment, national income and GDP.

As the research performed in 2009 shows (OECD 2009), positive structural changes caused by the crisis consist of stimulation of innovations through entrepreneurship acceptance; investments to innovative infrastructure that induce researches and development; green investments; coordinating employees' skills; directing market participants to innovative investments and confronting the activities which earlier had too large barriers. The crisis influences innovation process and most other factors of long-run growth. According to the OECD research, investments and innovations, which are measured by the indicators of the number of the USA and European patents, dropped in most countries during crises. Recently performed Business Enterprise Expenditure on R\&D (BERD) analysis (Fig. 8) has demon- 


$$
15
$$
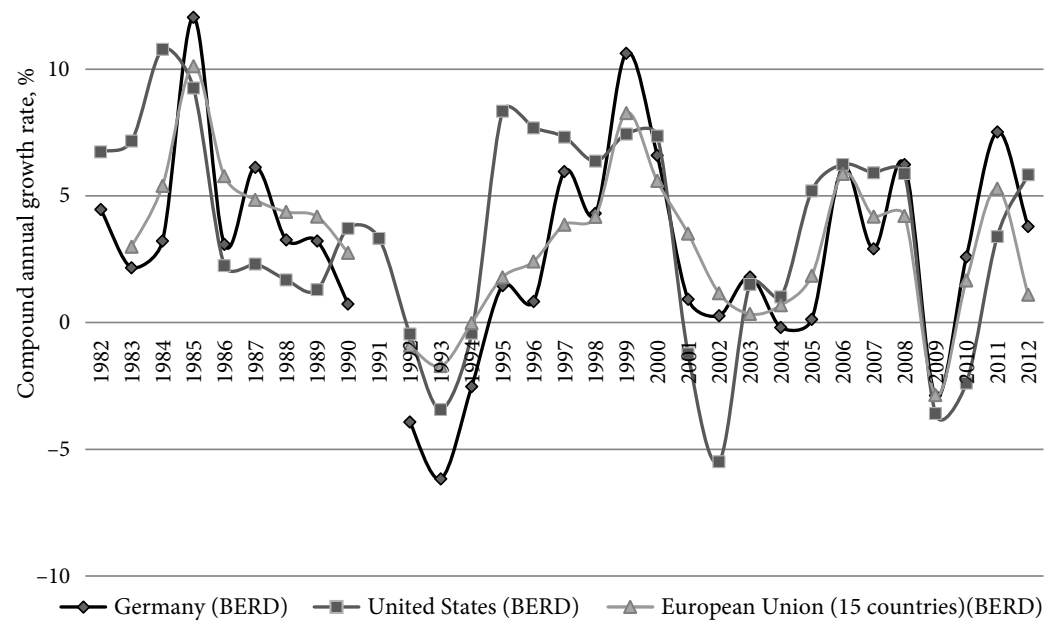

Fig. 8. The impact of the business cycle on innovations BERD

(Business Enterprise Expenditure on R\&D), yearly growth rates

Source: Authors' calculations based on the OECD data (2015).

strated that during economic crises similar tendencies are preserved except for amplitude shift between countries. In both 2002 and 2009 the sharpest decline of BERD was observed in the United States; however, in 2009 the decline was smaller and the dynamics of BERD in the European Union was close to that of the US.

It is noticed that most existing innovative enterprises were formed either during "creative destruction" or they grew rapidly after the crisis.

The crisis decreases the frequency of emergence of new enterprises because the accessibility to finance resources decreases. A new but very important factor for the impact of economic cycle on innovations is the expansion of global supply chains. These chains become very important sources of new knowledge generation and learning. Global distribution networks render technical knowledge, information about foreign markets and, most importantly, business contacts, international partners for enterprises. Thus the fall of trade and investment flows can cause destructive outcomes for global transmission of knowledge. Negative impact of crises manifests in devaluation of human capital and stimuli to develop greener economy. However, historical experience shows that crises create conditions for developing innovations and growth.

It is also proved that crises can even strengthen innovative activities. Anti-crisis policy means can ensure stimuli to implement innovations. As it is stressed in the OECD research, suppression of negative impact of the crisis on innovations is important because the crisis significantly strengthens the impact of known market mistakes in innovation financing. During the crisis innovations are even considered to be more risky than some long-run investments. National policy can reduce obstacles for entrepreneurship and industry renovation in the slowdown. 


\section{Features of the impact of recession and innovations on manufacturing in small open economy (the case of Lithuania)}

Lithuanian industry has not succeeded in avoiding difficulties of economic recession because Lithuanian market is open and small, and it is complicated enough to survive in international competition for such small players.

Lithuanian textile industry enterprises had the ability to use the situation in intercepting orders of foreign partners and in reorganizing production and creating products of higher value added.

In timber industry it became possible to strengthen competitive positions by modernizing production and properly choosing distribution channels. Cooperation of Lithuanian furniture industry with IKEA multinational group insured not only about $90 \%$ of the total furniture export through this channel, but also steady growth in the production of this industry. Even in the year of the 2009 crisis, when the decline of Lithuania's GDP was 18\%, the furniture industry reached $7 \%$ growth.

Especially during economic recession the relevance of decisions of innovative industry enterprises and those related to ecology, saving, security as well as success of such enterprises becomes evident. Production of biofuel in chemistry industry which grew twice during the recession period may be mentioned as an example. As one of the warrants for success in chemistry industry were successful transactions of product sales to foreign research companies.

The ability to pull in foreign investors determines the success of most industrial enterprises. This is especially relevant for the production of manufacturing branch of other non-metal mineral products, where the great importance is given to technological lines, e.g. the line of producing dry cement using new technology.

More than one Lithuanian manufacturing enterprise was redeemed from economic recession by the orders from hegemonic foreign partner enterprises. However, strong partnerships with competitive foreign enterprises which are able to sustain difficult economic conditions were not the only way to rescue Lithuanian enterprises. The Foreign Direct Investments (FDI) had a no less important role in the situation. Technology modernization, improving employee qualification, investments to Research and Technological Development (R\&D) as well as innovation implementation were very important for Lithuanian enterprises during economic recession.

Development of Lithuanian manufacturing enterprises faces difficulties due to costly raw materials. Gas prices should be mentioned as a special case. This stock is much more expensive for Lithuanian enterprises than for their rival companies located abroad. The solution to this problem is complicated because the only supplier of this stock for Lithuanian industrial enterprises is Gazprom. Enterprises operating in chemistry industry, especially if they produce fertilizers the basic raw material of which is natural gas, are particularly sensitive to the price of gas. Development of exports of Lithuanian industrial enterprises and competitiveness growth are blocked not only by growing prices of raw materials due to currency risks (part of the stocks is bought in dollar zone, and the final output is realised in the Eurozone); another relevantly negative impact is made by the growth in the prices of energy resources, which especially affects decisions of foreign investors to develop business in Lithuania in a negative way. 
It is necessary to mention not only costly raw materials or diminished demand in foreign and local markets, but also such factors as lack of specialists, especially of highest qualification, among the factors limiting activities of the main Lithuanian industrial enterprises during economic recession. Metal industry enterprises and textile industry enterprises, which are not able to fulfil the orders of large foreign partners, face this problem. The lack of qualified workforce limits the activities of mechanical engineering and equipment production branch enterprises. Finally, one more negative factor in these industry branches is still unsolved problem of vocational training.

\section{Conclusions}

Almost each enterprise and particularly small and medium-sized enterprises in financial crunch face the basic problem, i.e. the lack of circulating assets. This problem became much more evident when economy was in recession and Lithuanian banks had performed especially unfavourable policy of enterprises crediting.

Very important factors for the impact of economic cycle on innovations are the consequences of the expansion of global supply chains. Not only have these chains become important catalysers of new knowledge generation and learning (as in IKEA and the Lithuanian furniture industry case), but they also could generate growth in the situation of economy collapse.

The analysis of the situation in manufacturing sectors of Lithuania during economic recession in 2007 to 2009 has revealed several characteristics of innovations for this period due to which Lithuanian manufacturing enterprises managed to successfully function and remain competitive as follows: the ability to intercept orders of foreign partners; the ability to reorganise production by focusing on ecological goods that create higher value added; a successful choice of distribution channels; the modernization of production; the ability to make successful sales transactions; and the employment of new technologies.

Possibilities for most enterprises to be competitive are limited by gaps in developing innovative activity. The problem is not only the lack of financing. Most enterprises do not resolve to make innovative decisions due to information lack, the absence of instruments stimulating innovative activity and difficulties faced by small and medium businesses in getting financing sources.

The influence of household consumption expenditure on the growth of GDP in Lithuania is described by the function close to linear, so we see the direct relation between these two variables. The impact of export on GDP is described by the convex function that has showed the declining influence of export on the GDP growth in the long-term perspective.

Therefore, contrary to the approach prevailing in transition countries, it is misleading to believe that the main impetus for long-term growth is export. The long-term GDP growth is impossible without the stimulation of household consumption expenditure growth.

For the period 2009 to 2013 the household consumption expenditure function has a convex shape, proving a diminishing role of this factor for the economic growth. The main reason for Lithuania to have such performance of the growth sources is the method which has been used to solve problems in after crisis period, namely labour deflation being the main 
method of balancing the states budged and getting good balance of payments of Lithuanian economy. When internal possibilities for economic growth were limited by the household consumption expenditure restrictions, business got the main niche and additional possibilities in export competition due to cheaper labour.

Modelling the consequences of such type of growth has showed a serious obstacle for the growth in a longer period, i.e. continuing high rates of labour emigration due to uncompetitive wages in Lithuania will erode one of the main growth factors in the long term. The only possibility for growth in such conditions will be through innovations the growth of which should faster than the decline of labour market.

\section{Acknowledgements}

This research is funded by a grant (No.IEP-01/2012) from the Research Council of Lithuania.

\section{References}

Acemoglu, D.; Johnson, S.; Robinson, J. 2002. Reversal of fortune: geography and institutions in the making of the modern world income distribution, Quarterly Journal of Economics 117(4): 1231-1294. http://dx.doi.org/10.1162/003355302320935025

Acemoglu, D.; Johnson, S.; Robinson, J. 2005. The rise of Europe: Atlantic trade, institutional change, and economic growth, American Economic Review 95(3): 546-579. http://dx.doi.org/10.1257/0002828054201305

Acemoglu, D.; Linn, J. 2004. Market size in innovation: theory and evidence from the pharmaceutical industry, Quarterly Journal of Economics 119(3): 1049-1090. http://dx.doi.org/10.1162/0033553041502144

Amdam, R.; Lunnan, R.; Ramanauskas, G. 2007. FDI and the transformation from industry to service society in emerging economies: a Lithuanian-Nordic perspective, Inzinerine Ekonomika - Engineering Economics (1): 22-28.

Barro, R. J. 1990. Government spending in a simple-model of endogenous growth, Journal of Political Economy 98(5): S103-S125. http://dx.doi.org/10.1086/261726

Barro, R. J. 1988. Government spending in a simple model of endogenous growth, NBER Working Papers 2588, National Bureau of Economic Research, Inc.1988.

Boguslauskas, V.; Adlyte, R. 2010. Evaluation of criteria for the classification of enterprises, Inzinerine Ekonomika - Engineering Economics 21(2): 119-127.

Brazinskas, S. 2010. Ekonominès krizès iššūkiai: prielaidos didinti Lietuvos ekonomikos konkurencinguma [online]. Lietuvos Respublikos ambasada Švedijos Karalystëje, 15-23 [cited 18 January 2015]. Available from Internet: http://value.lt/failai/dowloadai/File/Viesasis\%20administravimas_SBraz_2010.pdf

Byerlee, D.; de Janvry, A.; Sadoulet, E. 2009. Agriculture for development: toward a new paradigm, Annual Review of Resource Economics 1: 15-31. http://dx.doi.org/10.1146/annurev.resource.050708.144239

Cekanavicius, L.; Kasnauskiene, G. 2009. Too high or just right? Cost-benefit approach to emigration question, Inzinerine Ekonomika-Engineering Economics (1): 28-36.

Celik, S.; Ozerkek, Y. 2009. Panel cointegration analysis of consumer confedence and personal consumption in the European Union, Journal of Business Economics and Management 10(2): 161-168. http://dx.doi.org/10.3846/1611-1699.2009.10.161-168

Ciegis, R.; Jurgaityte, R.; Rakickas, A.; Kareivaite, R. 2008. The analysis of socio-economic progress and future perspectives in the new EU members, Transformations in Business \& Economics 7(2): 34-54. 
Fisher-Vanden, K.; Ho, M. 2010. Technology, development, and the environment, Journal of Environmental Economics and Management 59(1): 94-108. http://dx.doi.org/10.1016/j.jeem.2009.08.002

Franklin, C. 2003. Why innovation fails. Spiro Press.

Grundey, D.; Toluba, B.; Pilinkus, D.; Verbauskiene, L. 2008. The role of institutional policy in developing innovative entrepreneurship in Lithuania, Transformations in Business \& Economics 7(2): 86-101.

Ickes, B. W. 1996. Endogenous growth models [online]. Department of Economics Penn State University University Park, PA 16802, 1-26 [cited 18 January 2015]. Available from Internet: http://econ.la.psu. edu/ bickes/endogrow.pdf

Jasinskas, E.; Simanaviciene, Z. 2008. Government's support for farmers' knowledge dissemination and its improvement, Inzinerine Ekonomika - Engineering Economics (3): 67-72.

Katircioglu, S. 2010. Trade and growth in a non-recognized small island state: evidence from the Turkish republic of Northern Cyprus, Journal of Business Economics and Management 11(1): 112-130. http://dx.doi.org/10.3846/jbem.2010.06

Kokocinska, M. 2009. The path of sectoral changes in large developed european countries: the Polish perspective, Transformations in Business \& Economics 8(3): 68-82.

Kroll, H.; Tagscherer, U. 2009. Chinese regional innovation systems in times of crisis: the case of Guangdong, Asian Journal of Technology Innovation 17(2): 101-128. http://dx.doi.org/10.1080/19761597.2009.9668675

Lupu, I.; Dumitrescu, D. 2010. Stock market reaction to news on macroeconomic growth. An event study analysis at the bucharest stock exchange, Transformations in Business \& Economics 9(1): 361-376.

Memon, J. A.; Demirdogen, R. E. 2009. Intellectual security in technology based learning environment in a globalization world, in Procedia - Social and Behavioral Sciences 1(1): 2552-2556. http://dx.doi.org/10.1016/j.sbspro.2009.01.450

OECD. 2009. Policy responses to the economic crisis: investing in innovation for long-run growth. OECD, 1-37. http://dx.doi.org/10.1787/20725345

OECD [online]. 2015 [cited 18 January 2015]. Available from Internet: http://stats.oecd.org/index. aspx?DatasetCode=MSTI_PUB

Pinto, H.; Guerreiro, J. 2010. Innovation regional planning and latent dimensions: the case of the Algarve region, Annals of Regional Science 44(2): 315-329. http://dx.doi.org/10.1007/s00168-008-0264-5

Ramsey, F. P. 1931. Foundations - essays in philosophy, logic, mathematics and economics. Humanities Press. 287 p.

Rebelo, S. 1991. Long-run policy analysis and long-run growth, Journal of Political Economy 99(3): 500-521. http://dx.doi.org/10.1086/261764

Romer, P. 1990. Endogenous technological-change, Journal of Political Economy 98(5): S71-S102. http://dx.doi.org/10.1086/261725

Saboniene, A. 2014. Quality mode of Lithuanian manufacturing industry's exports, Inzinerine EkonomikaEngineering Economics 25(4): 450-457.

Smolny, W. 2003. Determinants of innovation behaviour and investment estimates for West-German manufacturing firms, Economics of Innovation and New Technology 12(5): 449-463. http://dx.doi.org/10.1080/1043859022000029230

Snieska, V.; Simkunaite, I. 2009. Socio-economic impact of infrastructure investments, Inzinerine Ekonomika - Engineering Economics (3): 16-25.

Solow, R. M. 1956. A contribution to the theory of economic growth, The Quarterly Journal of Economics 70(1): 65-94. http://dx.doi.org/10.2307/1884513

Statistics Lithuania data [online]. 2015 [cited 18 January 2015]. Available from Internet: http://db1.stat. gov.lt/statbank/default.asp?w=1920 
Stiglitz, J. E. 1993. Endogenous growth and cycles. NBER Working Paper No. 4286, 1-57.

Tvaronavicius, V.; Tvaronaviciene, M. 2008. Role of fixed investments in economic growth of country: Lithuania in European context, Journal of Business Economics and Management 9(1): 57-64. http://dx.doi.org/10.3846/1611-1699.2008.9.57-64

Umbrasiene, G. 2014. Analysis of cyclical sensitivity in traditional and new sectors: the case of Lithuanian economy, Inzinerine Ekonomika - Engineering Economics 25(4): 420-426.

Wedemeier, J. 2010. The impact of the creative sector on growth in German regions, European Planning Studies 18(4): 505-520. http://dx.doi.org/10.1080/09654311003593473

Yan, X. F. 2009. Research on the relationship between LMIE's technological innovation and economic growth, in Proceedings of 2009 International Conference of Management Science and Information System 25-27 September 2009, Jiaozuo, China, 1(4): 427-431.

Zavadskas, E. K.; Turskis, Z.; Kildienè, S. 2014. State of art surveys of overviews on MCDM/MADM methods, Technological and Economic Development of Economy 20(1): 165-179. http://dx.doi.org/10.3846/20294913.2014.892037

Zickiene, S. 2007. Cooperation in environmental governance - a new tool for environment protection progress, Inzinerine Ekonomika - Engineering Economics (3): 42-50.

Vytautas SNIESKA. PhD in Economics (1982), Professor at the Department of Economics, Economics and Business Faculty of Kaunas University of Technology, Project researcher of the Long term Institutional Economic Research programme, theme - Modelling of Credit Markets Shocks Consequences for Economy and Means for the Corrections of these Consequences. A member of the editorial boards of several research journals. Research interests: innovations policy and economics, international competitiveness, credit markets shocks consequences for economy, business environment forecasting.

Gitana VALODKIENE. A PhD in Economic sciences, Lecturer at the Department of Economics, Economics and Business Faculty of Kaunas University of Technology, Project researcher of the Long term Institutional Economic Research programme, theme - Modelling of Credit Markets Shocks Consequences for Economy and Means for the Corrections of these Consequences. Research interests: innovations policy and economics, international competitiveness, credit markets shocks consequences for economy, business environment forecasting. 